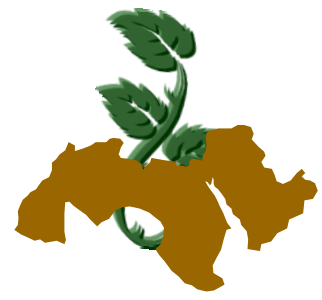

\title{
USE OF ESSENTIAL OILS FOR CONTROLLING BACTERIAL ANGULAR LEAF SPOT DISEASE OF CUCUMBER
}

\author{
Gomah', A.A.
}

\author{
1- Plant Path. Res. Instit., Agric. Res. Centre, Giza, Egypt
}

Keywords: Angular leaf spot, Pseudomonas syringae pv. lachrymans, Essential oils, Cucumber

\begin{abstract}
Activity of commercially and purified essential oils of aloes, anise, black cumin, caraway, carnation, cumin, fennel, garlic, jojoba, lavender, onion, rue and thyme were tested against growth of Pseudomonas syringae pv. lachrymans, caused bacterial angular leaf spot disease of cucumber, in vitro and in vivo. Three essential oils had an inhibitory effect, based on the determination of the minimum inhibitory concentrations (MICs 0.25$2.0 \%$ ). Carnation, fennel and thyme were inhibitory at MIC $0.5 \%$. The three mentioned oils showed considerable variation in the inhibitory effect by the disk diffusion method, though the recognized similarity in fumigation treatments. The greatest activity was recorded with thyme $(18 \mathrm{~mm})$ followed by carnation $(15 \mathrm{~mm})$ while fennel showed the lowest effect $(9 \mathrm{~mm})$. Soaking cucumber seeds of different cultivars in $2 \%$ emulsified oils for a period ranging from 0.25 to 4 hours significantly decreased the percentage of germination. Shorter duration of seed soaking, 0.25 to 0.5 hours, showed lower deleterious effect on germination and fennel oil showed greater harmful effect. In greenhouse experiments, the three oils significantly controlled the disease incidence compared to the check treatment, being more pronounced for thyme oil followed by fennel and carnation oils. Analysis of the essential oils in concern showed eugenol, dieugenol, linolenic acid, methyl chavicol (estragol), anisole and thymol, as an active ingredients.
\end{abstract}

\section{INTRODUCTION}

Angular leaf spot is an important disease on cucumber and different cucurbit species as well.
Symptoms are usually more severe where moisture and atmospheric humidity either in field or in greenhouse, are prevailing. The disease was first observed in 1913 in USA and in 1924 in Denmark (Hellmers, 1958). The first record of the disease in Egypt was made during 1989 and 1990 seasons, at El-Minia Governorate which showed an outbreak of a bacterial disease on cucumbers in a greenhouse (El-Sadek et al 1992). More recently Galal et $\boldsymbol{a l}$ (2003) reported the disease in open cucumber fields in different Minia regions. The first authentic description of the causal organism Pseudomonas syringae pv. lachrymans of angular leaf spot of cucumber was made by Smith and Bryan (1915).

The disease control in general has principally been suggested by hot water treatment or dry heating of seeds (Severin et al 1973 and Umekawa \&Watanabe, 1978), laser and gamma irradiation (Cholakov and Kona, 2004) and non specific induced resistance (Galal et al 2003 and Mahmoud, 2007). The use of essential oil in control of bacterial plant pathogen as Clavibacter michiganensis sub sp michiganensis was demonstrated by (Daferera et al 2003 and Juliano et al 2000). Marino et al (1999) showed antibacterial activity of essential oils toward 9 strains of Gram negative bacteria and 6 strains of Gram positive bacteria.

Analysis of essential oils to determine the chemical composition and active gradients have been tried by many investigators. Hudak and Thompson (1996) found triacylglycerol, free fatty acids, sterol and wax esters, along with phosphatidic acid and diacylglycerol were isolated from carnation petals. Bilia et al (2002) showed the highest levels of volatile constituents in commercial fennel. They detected Anethole and/or anisaldehyde as a main constituents of all samples as well as methychavicol, eugenol and fenchone in most samples. Car- 
vone was present only in some samples and camphor in others. The volatile constituents of only one instant included limonene and alpha-terpineol. Coelho et al (2003) found that the main compounds identified in the oils were fenchone, estragol and (E)-anethole. Pino et al (1997) found 25 compounds in Thymus vulgaris L. identified as, thymol, gamma-terpinene and P-cymene as the major constituents.

Environment safety as a greatest aim in conservation of our natural resources free from pesticides, made it necessary to think over the natural products for disease control. Therefore, this work was undertaken to study the possible use of some natural oils in disease control. Experiments were carried out under laboratory and greenhouse conditions.

\section{MATERIALS AND METHODS}

\section{Source of essential oils used}

Thirteen commercially purified essential oils were obtained from the domestic market in Cairo Egypt. Common and Latin names as well as the plant families of the respective essential oils are given in Table (1).

\section{Bacterium and inoculum preparation}

Virulent isolate of $P$. syrinagae pv. lachrymans (Psl 517) was obtained from the Bacterial Diseases Dept. Plant Pathology Res. Institute,
ARC, Giza, Egypt. The isolate was grown in King's B broth at $28 \mathrm{C}$ for 48 hours and optically standardized to gives $10^{8}$ colony forming units (cfu) $\mathrm{ml}$. The standardized broth cultures were used for seed soaking treatments.

\section{Effect of essential oils on growth of $P$. syringae pv. lachrymans in vitro}

\section{A- Determination of the minimum inhibitory concentration (MIC) of the essential oil}

The MIC of the essential oils was determined by using the agar dilution method (Hammer et al 1999) with a final $0.5 \%(\mathrm{v} / \mathrm{v})$ concentration. A series of dilutions of each essential oil were ranged from 0.25 to $2 \%(\mathrm{v} / \mathrm{v})$ was prepared in King's B medium with $0.5 \%(\mathrm{v} / \mathrm{v})$ Tween-80 as an emulsifying agent. The medium was poured in sterilized plates.

These Plates were dried prior to inoculation with $P$. lachrymans. Inoculation was carried out by spot inoculation $(10 \mu \mathrm{l})$ of bacterial broth replicated three times. Plates without oil were used as a positive growth control. Inoculated plates were incubated at $28 \mathrm{C}$ for $48 \mathrm{hrs}$.

The MICs were determined as the lowest concentration of the oil inhibiting the visible growth of the bacteria on the agar plate.

\section{B- Fumigation method}

Plates containing King's B medium were inoculated with bacterial suspension $(0.1 \mathrm{ml})$ of

Table 1. Essential oils tested and their respective plant names and families

\begin{tabular}{|lll|}
\hline \multicolumn{1}{|c}{ Plant oils } & \multicolumn{1}{c|}{ Scientific name } & \multicolumn{1}{c|}{ Family } \\
\hline Aloes & Aloe barbadensis & Liliaceae \\
Anise & Pimpinella anisum L. & Umbelliferae \\
Black cumin & Nigella sativa L. & Ranunculaceae \\
Caraway & Caryum carvi L. & Umbelliferae \\
Carnation & Eugenis caryophylla & Myrtaceae \\
Cumin & Cuminum cyminum & Umbelliferae \\
Fennel & Foeniculum vulgare Mill & Umbelliferae \\
Garlic & Allium sativum L. & Liliaceae \\
Jojoba & Simmondsia chinensis & Buxaceae \\
Lavender & Lavandula officinalis L. & Labiatae \\
Onion & Allium cepae L. & Liliaceae \\
Rue & Ruta graveolens & Rutaceae \\
Thyme & Thymus vulgaris L. & Labiatae \\
\hline
\end{tabular}


$P$. lachrymans. The plates were kept inverted to dry. The tested essential oil $(0.1 \mathrm{ml})$ was placed on the lid of each plate that taped by double layer of parafilm. The control plates were prepared in the same way except that the essential oil was not placed on the lid. All plates were incubated at 28C for 48 hours. Efficiency of oils were determined according to growth of the bacterium (Reuveni $\boldsymbol{e t}$ al 1984).

\section{C- Filter paper disc method}

The filter paper discs were used to evaluate the antimicrobial activity essential oils. Agar plates of King's medium B plates were seeded by $0.1 \mathrm{ml}$ P.lachrymans, standardized to give $10^{8} \mathrm{cfu} / \mathrm{ml}$. Filter paper discs (Whatman No.1, 5mm diameter) impregnated with $5 \mu 1$ of essential oil were applied to the agar surface. The plates were incubated at $28 \mathrm{C}$ for 24 hours. The diameters of inhibition zones were measured millimeters.

\section{Aanalysis of the effective essential oils}

Chemical analysis of the effective essential oils of carnation, fennel and thyme was carried out by using GC-mass Aglient 68. The stationary phase was: HP INNO wax $30 \mathrm{M}$ length $\mathrm{x} 0.25 \mathrm{~mm}$ D/N 19091 N-133.

The Carrier gas was: Helium $42 \mathrm{~cm} / \mathrm{sec}$, 24 psi $\left(120^{\circ} \mathrm{C}\right)$ and the flow was $1.8 \mathrm{~mL} / \mathrm{min}$. The oven temperature was $120^{\circ} \mathrm{C}$ for $1 \mathrm{~min} ., 120-250^{\circ} \mathrm{C}$ at $10^{\circ} \mathrm{C} / \mathrm{min}$ and $250^{\circ} \mathrm{C}$ for $5 \mathrm{~min}$. While injection volume was $1 \mu l$.

This analytical procedure was done in Biotechnology Unit, Plant Pathology Res. Institute, ARC, Giza, Egypt.

\section{Effect of essential oils on seed viability}

Carnation, fennel and thyme emulsified oils (2\%) were used for soaking Beit alpha, Madina and Smart 529 cucumber seeds for $0.25,0.5,1,2$ and 4 hours. Another set of cucumber seeds were soaked in water to serve as control. Samples (20 seeds each treatment) were kept at about $25^{\circ} \mathrm{C}$ between moistened layers of filter paper in Petri dishes for four days. The percentage of germination were determined.

Effect of essential oils on severity of bacterial angular leaf spot disease of cucumber in vivo

Essential oils of carnation, fennel and thyme were tested against the used isolate of Pesudomons syringae pv. lachrymans,.. Seed inoculation
Smart 529 cucumber was made by soaking for two hours in a bacterial King's medium B broth standardized to give $10^{8} \mathrm{cfu} / \mathrm{ml}$.. After inoculation seeds were transferred to a different emulsified oils at the concentrations $0.5,1$ and $2 \%$ for either 15 or 30 minutes.

\section{Disease assessment}

Disease severity was estimated after 30 days from planting using modified scale of Horsfall and Barrett (1945). The modified scale was from 0 to 5 , where $0=$ no disease, $1=1-6 \%, 2=7-25 \%$, $3=26-75 \%, 4=76-94$ and $5=95-100 \%$ of infected tissue.

Experiments were assigned completely randomize design of factorial arrangement in three replications and the statistical analysis of variance was done as outlined by Steel and Torrie (1980).

\section{RESULTS AND DISCUSSION}

\section{Effect of essential oils on growth of $P$. syringae pv. lachrymans, in vitro}

\section{A- The minimum inhibitory concentration (MIC) of the essential oil}

Table (2) shows the MIC of the oils in concern. The inhibitory effect was observed to increase at higher concentrations $(0.5 \%)$ of carnation, fennel and thyme oils. All oils used had no inhibitory effect on the pathogen growth at $0.25 \%$. Oils of aloes, anise, black cumin, caraway, cumin, garlic, jojoba, lavender, onion and rue had no effect either at high or low concentrations.

The result of the study revealed that out of 13 essential oils tested, three oils namely carnation, fennel and thyme had an antimicrobial effect against growth of $P$. syringae pv. lachrymans. They completely inhibited the growth of the studied bacterium in $9 \mathrm{~cm}$ diameter, tightly sealed, plates, as well as in $0.5 \%$ emulsified oils (MIC) impregnated with the agar medium. The disk diffusion method, however, showed considerable variation in the inhibitive effect of the three oils in concern. There were 10 tested essential oils that had no antimicrobial effect against the studied bacterium at the concentration of $2 \%$ by using MIC method. The results showed that the carnation, fennel and thyme oils had an antibacterial volatile phase that inhibited the growth of the tested bacterium. These volatile antibacterial compound(s) had a high diffusion potential through 
Table 2. Minimum inhibitory concentrations of the essential oils against growth of $P$. syringae pv. lachrymans

\begin{tabular}{|lcccc|}
\hline & \multicolumn{5}{c|}{ Concentrations \% } \\
\cline { 2 - 5 } Plant oils & 0.25 & 0.50 & 1.0 & 2.0 \\
\hline Carnation & + & - & - & - \\
Fennel & + & - & - & - \\
Thyme & + & - & - & - \\
Aloes & + & + & + & + \\
Anise & + & + & + & + \\
Black cum- & + & + & + & + \\
in & & & & \\
Caraway & + & + & + & + \\
Cumin & + & + & + & + \\
Garlic & + & + & + & + \\
Jojoba & + & + & + & + \\
Lavender & + & + & + & + \\
Onion & + & + & + & + \\
Rue & + & + & + & + \\
\hline
\end{tabular}

+ Present.

- Absent.

King's medium B agar, as shown by the recorded antibacterial effect, contrary to the 10 noneffective oils that had nonihibitory effect against tested bacterium. These results are in accordance with those obtained by Abd El-Aziz (2002) who studied inhibitory effect of essential oils against $R$. solanacearum by fumigation method and contact methods.

The antimicrobial action of the three essential oils in concern against $P$. syrignae pv. lachrymans by using the MIC method was recorded with carnation oil, fennel oil and thyme oil and is in accordance with Hammer et al (1999); Juliano et al (2000) and Mahmoud et al (2004).

\section{B- Fumigation method}

Fumigation method was evaluated for the three essential oils carnation, fennel and thyme that showed inhibitory effect in the previous testing method. The absence of growth of $P$. lachrymans on the surface of plates was scored positive effect (Table 3).

The inhibition effect of the three effective essential oils were similar by using fumigation method and the values recorded were $\geq 9 \mathrm{~cm}$. The results were similar to those obtained by Reuveni et al (1984).

\section{C- Filter paper disc method}

Inhibition zones method was used for the evaluation of the three essential oils (Table 3). The essential oil of thyme showed the greatest inhibitory effect against growth of P.lachrymans, followed by carnation, while the fennel showed the lowest effect.

Table 3. Efficiency of some oils against growth of $P$. syringae pv lachrymans, using two methods

\begin{tabular}{|ccc|}
\hline & $\begin{array}{c}\text { Filter paper } \\
\text { disc method } \\
(\mathrm{mm})\end{array}$ & $\begin{array}{c}\text { Fumigation } \\
\text { method } \\
(\mathrm{mm})\end{array}$ \\
\hline Carnation & 15 & $\geq 90$ \\
Fennel & 9 & $\geq 90$ \\
Thyme & 18 & $\geq 90$ \\
\hline
\end{tabular}

Finally, by using the filter paper disk method, effect of the three essential oils varied. The thyme oil had the highest inhibitory effect $(18 \mathrm{~mm}$ in diam.) followed by the carnation oil $(15 \mathrm{~mm})$, while fennel oil had the lowest effect $(9 \mathrm{~mm})$. Similar results were also reported by Daferera et al (2003) and Mahmoud et al (2004). On the positive activities of many essential oils against Gram negative and positive bacteria.

\section{Chemical composition of the effective essential oils}

Chemical composition of the essential oils, determined by GC-mass are shown in Table (4) and Figs. (1-3). The macro components of carnation oil are methyl lionolelaidate $(36.5 \%)$, linoleic acid (8.6\%), Ethyl vanillin PG acetal (6.20\%); in fennel oil eugenol (35.29\%), nitrophenylacetic acid $(15.43 \%)$ and hexahydrofarnesyl acetone (11.38\%); in thyme oil are anisol trimethyl (19.67\%), alpha tokoferol $(19.09 \%)$ and squalene $(5.06 \%)$. 
Table 4. Chemical composition of carnation, fennel and thyme essential oils

\begin{tabular}{|c|c|c|c|}
\hline \multirow{2}{*}{ Component $\%$} & \multicolumn{3}{|c|}{ Oils } \\
\hline & Carnation & Fennel & Thyme \\
\hline Ethyl vanillin $\mathrm{PG}$ acetal* & 6.20 & - & - \\
\hline Hydroquinone dimethyl & 2.34 & - & - \\
\hline Linoleic acid & 8.60 & - & 42.24 \\
\hline Methyl lionolelaidate & 36.50 & - & - \\
\hline Ethyl cholesterol & 1.87 & - & - \\
\hline Dehydro dieugenol & 0.32 & - & - \\
\hline Alpha monoolein & 0.70 & - & - \\
\hline Jasmine & 2.28 & - & - \\
\hline Methyl divinyl acetylene & - & 1.71 & - \\
\hline Fenylhydrazine & - & 4.35 & - \\
\hline Methyl chavicol (Estragol) & - & 4.32 & - \\
\hline Crotonic acid & - & 3.11 & - \\
\hline Diacetin & - & 0.64 & - \\
\hline Ledol & - & 5.16 & - \\
\hline Eugenol & - & 35.29 & - \\
\hline Nitrophenylacetic acid & - & 15.43 & - \\
\hline Glycidyl phenyl ether & - & 4.00 & - \\
\hline Myristinic acid & - & 1.62 & - \\
\hline Mentho furan & - & 0.72 & - \\
\hline Hexahydro farnesyl acetone & - & 11.38 & - \\
\hline Dill ether & - & 0.94 & - \\
\hline Profilurain & - & 1.08 & - \\
\hline Cuminon & - & 0.76 & - \\
\hline Thymol & - & - & 1.03 \\
\hline Anisol trimethyl & - & - & 19.67 \\
\hline Squalene & - & - & 5.06 \\
\hline Tetracosane & - & - & 3.18 \\
\hline Alpha tokoferol & - & - & 19.09 \\
\hline Unknown & 41.14 & 10.46 & 9.76 \\
\hline
\end{tabular}

$* \mathrm{PG}=$ Propylene glycol 


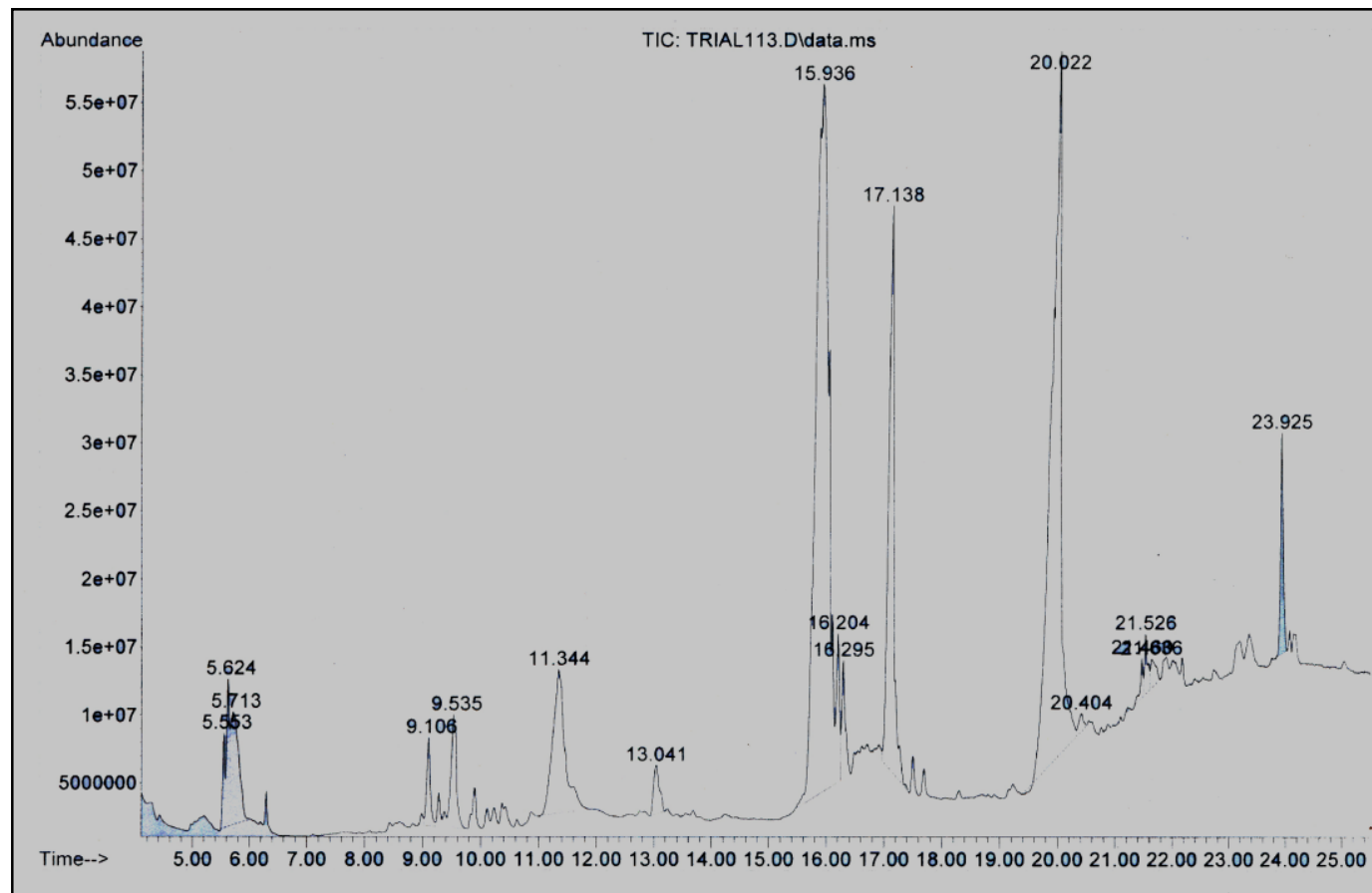

Fig. 1. Shows the GC-mass chromatogram of carnation oil

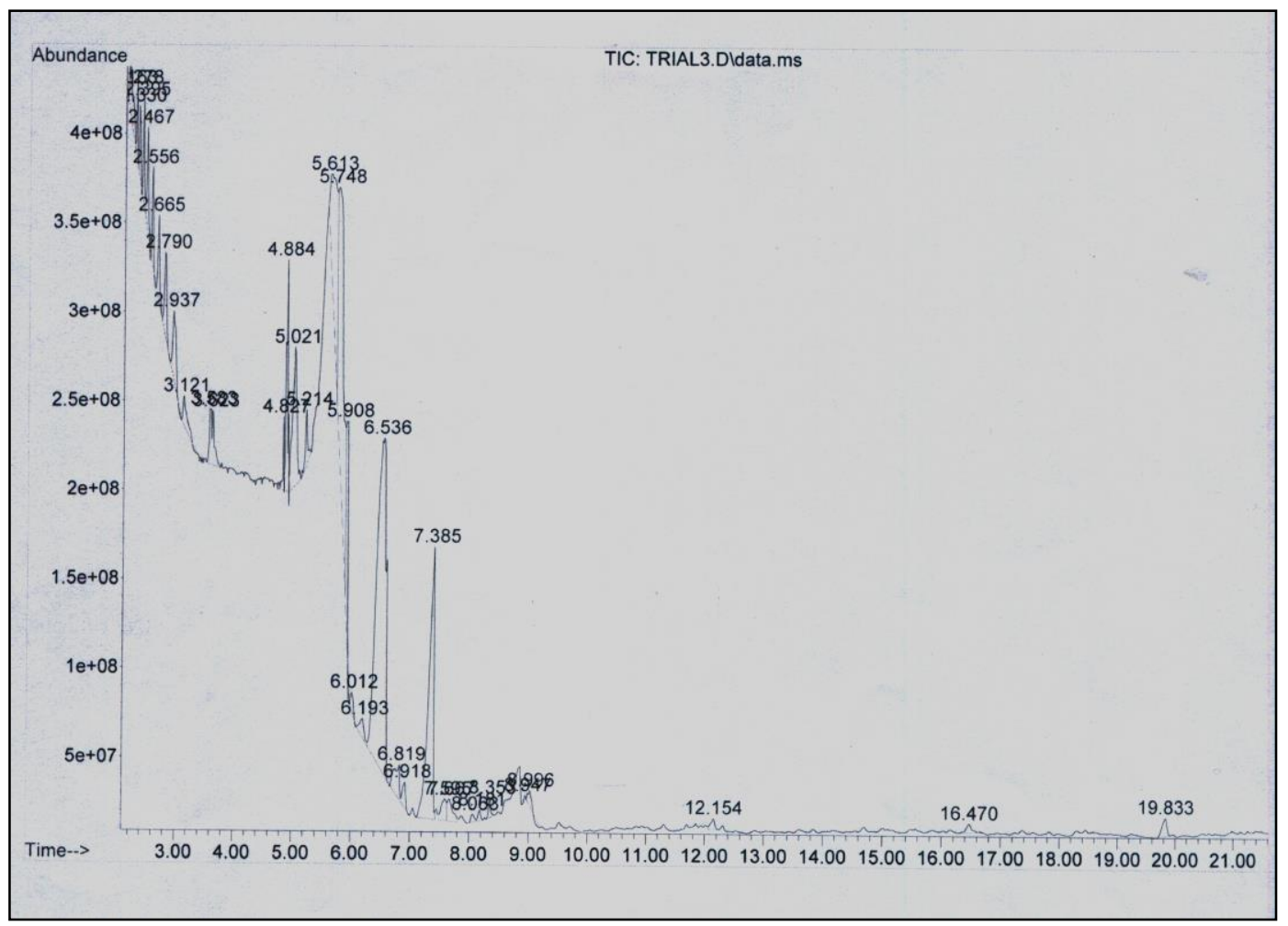

Fig. 2. Shows the GC-mass chromatogram of fennel oil 


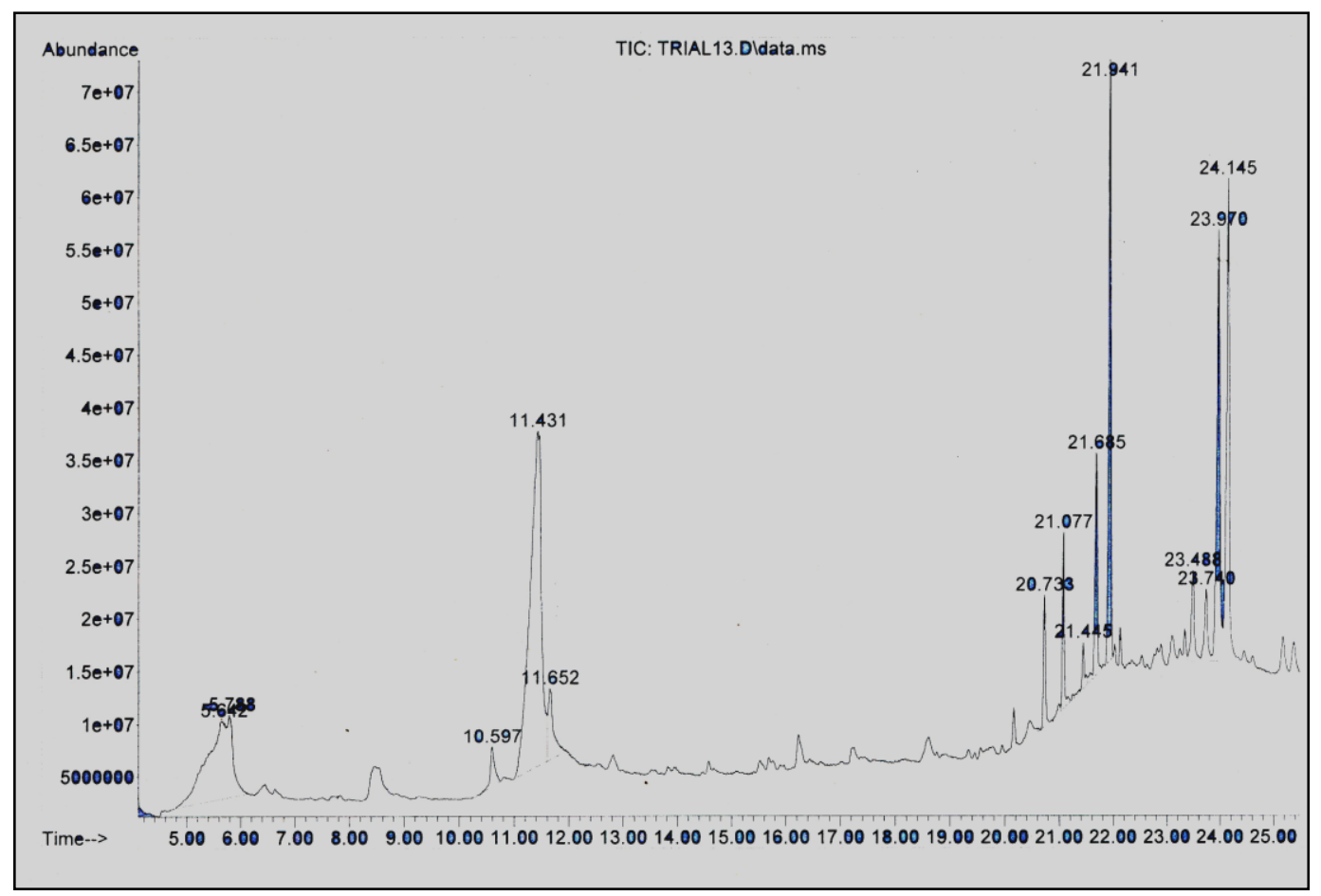

Fig. 3. Shows the GC-mass chromatogram of thyme oil

\section{Effect of essential oils on seed viability}

Data in Table (5) show the effect of soaking different cultivars of cucumber seeds in $2 \%$ emulsified oils for different periods on the percentage of seed germination. Data showed that soaking seeds of different cultivars for a period ranging from 0.25 to 4 hours significantly decreased the percentage of germination. Short term duration of seed soaking 0.25 to 0.5 hours in all individually tested emulsified oils, showed less deleterious effect on germination, though fennel oil had a harmful effect on seed viability as shown by a decrease in seed germination in all cultivars, especially at longer duration of soaking.

\section{Effect of different emulsified essential oils on severity of bacterial angular leaf spot disease of cucumber, in vivo}

Data in Table (6) shows that the effect of soaking cucumber seeds inoculated with $P$. syringae pv. lachrymans in different emulsified oils on the percentage of angular leaf spot disease development. Results showed that soaking cucumber seeds in any of the emulsified oils significantly decreased the angular leaf spot disease development compared to control treatment. Thyme oil had the highest effect, followed by fennel and carnation oils. No significant differences were observed between different periods and / or different oils concentrations.

The essential oils effective against growth of $P$. syringae pv. lachrymans in vitro were further tested in vivo against cucumber angular leaf spot in greenhouse.

The use of these oils as seed soaking was evaluated at three concentrations $(0.5,1.0$ and $2.0 \%)$ each for two dipping periods (15 and $30 \mathrm{~min}$.). All treatments were effective in reducing the disease compared with the control. This may be attributed to the lethal effects of some effective components as methyl lionolelaidate $(36.5 \%)$, linoleic acid $(8.6 \%)$ and ethyl vanillin PG acetal (6.2\%) in carnation oil. While, in fennel oil eugenol (35.29\%); nitrophenylacetic acid $(15.43 \%)$ and hexahydro farnesyl acetone $(11.38 \%)$ could be attributed as well. Finally, in thyme oil, linoleic acid were $(42.24 \%)$; anisol trimethyl (19.67\%) and alpha tokoferol (19.09\%), may be referred to other active ingredient such as hydroquinone dimethyl $(2.34 \%)$, and dehydro dieugenol $(0.32 \%)$ in carnation oil may also be 
Table 5. Effect of different emulsified oils (2\%), at different soaking peliods on germination of seeds of different cucumber cultivars

\begin{tabular}{|lccccc|}
\hline \multirow{2}{*}{ Cucumber cultivars } & \multirow{2}{*}{$\begin{array}{c}\text { Soaking periods } \\
\text { (hours) }\end{array}$} & \multicolumn{4}{c|}{ Germination (\%) } \\
\cline { 3 - 6 } & 0.25 & 98.3 & 90.0 & 86.7 & 91.7 \\
& 0.5 & 96.7 & 90.0 & 85.0 & 90.6 \\
Carnation oil & 1.00 & 91.7 & 88.3 & 80.0 & 86.7 \\
& 2.00 & 86.7 & 83.3 & 76.7 & 82.2 \\
& 4.00 & 83.3 & 78.3 & 70.0 & 77.2 \\
\hline \multirow{4}{*}{ Fennel oil } & 0.25 & 95.0 & 88.3 & 80.0 & 87.8 \\
& 0.5 & 91.7 & 83.3 & 75.0 & 83.3 \\
& 1.00 & 80.0 & 75.0 & 70.0 & 75.0 \\
& 2.00 & 71.7 & 73.3 & 66.7 & 70.6 \\
Thyme oil & 4.00 & 65.0 & 63.3 & 58.3 & 62.2 \\
& 0.25 & 96.7 & 90.0 & 86.7 & 91.1 \\
& 0.5 & 96.7 & 90.0 & 86.7 & 91.1 \\
& 1.00 & 90.0 & 88.3 & 81.7 & 86.7 \\
Check & 2.00 & 86.7 & 83.3 & 75.0 & 81.7 \\
& 4.00 & 83.3 & 81.7 & 71.6 & 78.9 \\
\hline
\end{tabular}

L.S.D. at 5\% Cultivars $(\mathrm{C})=2.809 \quad$ Hours $(\mathrm{H})=3.062 \quad$ Oils $(\mathrm{O})=3.024$

$\mathrm{CxH}=\mathrm{N} . \mathrm{S} \quad \mathrm{CxO}=\mathrm{N} . \mathrm{S} \quad \mathrm{HxO}=7.25 \quad \mathrm{CxHxO}=\mathrm{N} . \mathrm{S}$

Table 6. Effect of different emulsified oils on severity of bacterial angular leaf spot disease of cucumber, using treated seeds with virulent bacterium of $P$. syringae pv. lachrymans, in vivo

\begin{tabular}{|lcccc|}
\hline \multirow{2}{*}{$\begin{array}{c}\text { Soaking periods } \\
\text { (minutes) }\end{array}$} & $\begin{array}{c}\text { Oils } \\
\text { concentrations } \\
\text { \% }\end{array}$ & $\mathbf{1 5}^{*}$ & $\mathbf{3 0} *$ & Mean \\
\cline { 3 - 5 } Carnation oil & 0.5 & 0.3 & 0.3 & 0.3 \\
& 1.0 & 0.3 & 0.3 & 0.3 \\
& 2.0 & 0.0 & 0.3 & 0.2 \\
\hline \multirow{3}{*}{ Fennel oil } & 0.5 & 0.6 & 0.6 & 0.6 \\
& 1.0 & 0.6 & 0.3 & 0.5 \\
& 2.0 & 0.0 & 0.0 & 0.0 \\
\hline \multirow{2}{*}{ Thyme oil } & 0.5 & 0.0 & 0.0 & 0.0 \\
& 1.0 & 0.0 & 0.0 & 0.0 \\
\hline Check & 2.0 & 0.0 & 0.0 & 0.0 \\
\hline
\end{tabular}

* Soaking periods in essential oils (minutes).

L.S.D. at $5 \%$

$\begin{array}{lll}\text { Minutes }(\mathrm{M}) & =\mathrm{N} . \mathrm{S} & \mathrm{MXC}=\mathrm{N} . \mathrm{S} \\ \text { Concentrations (C) }=\text { N.S } & \text { MXO }=\text { N.S } \\ \text { Oils }(\mathrm{O}) & =0.295 & \text { MXCXO }=\text { N.S }\end{array}$

Arab Univ. J. Agric. Sci., 16(1), 2008 
indicated, in fennel oil cuminon $(0.76 \%)$, glycidyl phenyl ether (4\%) and methyl chavicol (estragol) (4.32). Finally, in thyme oil, tetracosane (3.18\%), squalene $(5.06 \%)$ and thymol (1.03).

The antibacterial effects of essential oils have been indicated by many investigators (Juliano et al 2000; Daferera et al 2003 and Mahmoud et al 2004). Different studies were concerned with chemical composition and active ingredients (Hudak \& Thompson, 1996; Pino et al 1997; Bilia et al 2002 and Coelho et al 2003). According to better understanding of the nature of essential oils, as an environment friendly compounds, great interest in trials concentrating on their use in plant diseases control in general and replacing pesticides use in particular (Mahmoud et al 2004).

\section{REFERENCES}

Abd El-Aziz, S.S. (2002). Integrated Management to Brown Rot Disease of Potato. pp. 4788. M.Sc. Thesis. Fac. Sci., Zagazig Univ., Egypt. Bilia, A.R.; G. Flamini; V. Taglioli; I. Morelli and F.F.Vincieri (2002). GC-MS analysis of essential oil of some commercial fennel teas. Food Chemistry, 76(3): 307-310.

Cholakov, D. and J. Kona (2004). Influence of presowing laser and gamma irradiation on the cucumber resistance towards angular spot (Pseudomonas lachrymans).Acta Horticulturae et Regiotecturae, 7(Supplement): 116-118.

Coelho, J.A.P.; A.P. Pereira; R.L. Mendes and A.M.F. Palavra (2003). Supercritical carbon dioxide extraction of Foeniculum vulgare volatile oil. Flavour and Fragrance Journal,18(4):316-319.

Daferera, D.J.; B.N. Ziogas and M. G. Polissiou (2003). The effectiveness of plant essential oils on the growth of Botrytis cinerea, Fusarium sp. and Clavibacter michiganensis subsp. michiganensis. Crop Protection, 22(1): 39-44.

El-Sadek, S.A.M.; N.R. Abdel-Latif;T.I. Abdel Gawad and N.A. Husein (1992). Occurrence of angular leaf spot disease in greenhouse cucumbers in Egypt. Egypt.J. Microbiol., 27(2): 157-175.

Galal, A.A.; El-S. Abdeou; H.M. Abd Alla and Hanaa M. M. Hassan (2003). Infectivity of Pseudomonas syringae pv. lachrymans to cucurbits as affected by gibberellic and/or salicylic acids. Assiut Journal of Agricultural Sciences, 34(2): 211-223.

Hammer, K.A.; C.F. Carson and T.V. Reley (1999). Antimicrobial activity of essential oils and other plant extracts. J. Appl. Microbiol., 86: 985990.

Hellmers, E. (1958). Bakteriesygdomme hos danske Kulturplanter. Den Kgl. Vet-og Landbohojskole, Kobenhavn (cited from Mortensen, 1992).

Horsfall, J.G. and R. W. Barrett (1954). An improved system for measuring diseases (abstr.) Phytopathology, 35: 655.

Hudak, K.A. and J.E. Thompson (1996). Flotation of lipid protein particles containing triacylglycerol and phospholipids from the cytosol of carnation petals. Physiologia Plantarum, 98(4): 810-818.

Juliano, C.; A. Mattana and M. Usai (2000). Composition and in vitro antimicrobial activity of the essential oil of Thymus herba barona Loisel growing wild in Sardinia. Journal of Essential Oil Research, 12(4): 516-522.

Mahmoud, S.M. (2007). Effect of abiotic and biotic treatments on bacterial angular leaf spot and phenolic compounds of cucumber. Arab. Univ. J. Agric. Sci. , Ain Shams Univ., Cairo, 15(2): 465-471.

Mahmoud, S.M.; A.A. Gomah and S.A. ElShall (2004). Efficiency of some natural oils for controlling crown gall disease caused by Agrobacteirum tumefaciens. Annals Agric. Sci., Ain Shams Univ., Cairo, 49(2): 699-707.

Marino, M.; C. Bersani and G. Coni (1999). Antimicrobial activity of the essential oils of Thymus vuglaris $L$. measured using a bioimpedometric method. Journal of Food Protection, 62(9): 1017-1023.

Mortensen, C. Nieves (1992). Seed-borne Bacterial Diseases. 80 pp. Danish Government, Institute of Seed Pathology for Developing Countries, Copenhagen, Denmark.

Pino, J.A.; M. Estrron and V. Fuentes (1997). Essential oil of thyme (Thymus vulgaris L.) grown in Cuba. Journal of Essential Oil Research, 9(5): 609-610.

Reuveni, R.; A.Fleischer and E. Putivesky (1984). Antimicrobial activity of essential oils: A 1976-1986 Literature Review-Aspects of the test methods. Phtopathol. Z. 110: 20-22.

Severin, V.; A. Popescu and S. Kupferberg (1973). Studies on the disinfecitno of cucumber seeds infected by Pseudomonas lachrymans. Analele Institutulut de Cercetaripentru Prorecia Plantelor, 9: 95-108. (c.f. Rev. Pl. Path., 53(8): 654-655).

Smith, E.F. and M.K. Bryan (1915). Angular leaf spot of cucumbers. Jour. Agr. Res. (U.S.) 5: 465-476. (c.f. Wiles and Walker, 1951).

Steel, R.G.D. and J.H. Torrie (1980). Principles and Procedures of Statistics. $2^{\text {nd }}$ Ed. McGrawHill, New York. 
Umekawa, M. and Y. Watanabe (1978). Dry heat and hot water treatments of cucumber seeds for control of angular leaf spot. Bulletin of the Vegetable and Ornamental Crops Research Station, B2: 55-61. (c.f. Rev. Pl. Path. 59(4): p.203).
Wiles, A.B. and J.C. Walker (1951). The relation of Pseudomonas lachrymans to cucumber fruits and seeds. Phytopathology 41: 10591064.
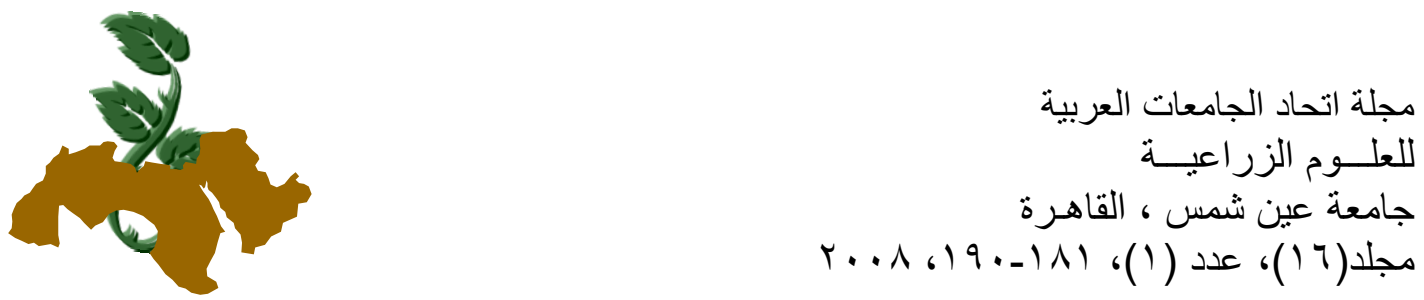

استخدام زيوت طيارة لمكافحة مرض التبقع البكتيرى الزاوى فى الخيار

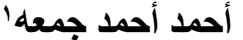 \\ 1ـ معهد بحوث أمراض النباتات ـ مركز البحوث الزراعية ـ الجيزة ـ مصر
}

[lY]

على المسبب المرضسى حيث كان قطر منقطة التثبط

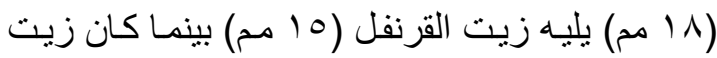

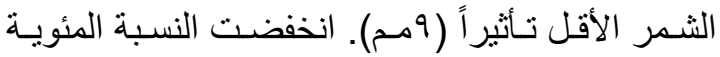




بين هب, • إلى ع ساعات، و كان لغمر البذور لقترات

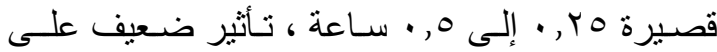





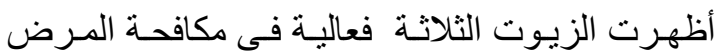

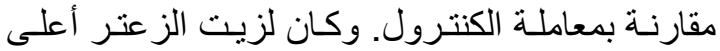
تأثير ، يليه زيت الثمر و القرنفل. ولقد وجد أن الزيـوت وتئن

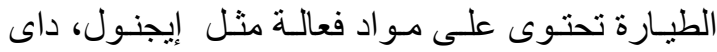

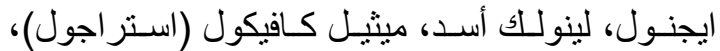

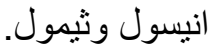

جريــت در اسـة معمليـة وتحــت ظـروف الصـوبة

لار اسة فعالية عدد من الزيوت الطيارة المنقاة تجارياً

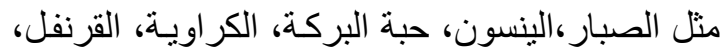

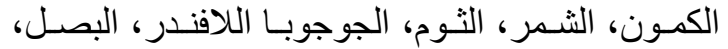

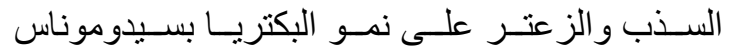

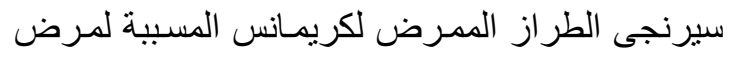




على أساس قياس قيمة أقل نركيز مثبط للتركيز ات من

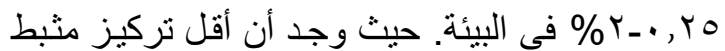


هو (0, • \%). كذلك تشابهت الزيوت الثناثنة فى تأثير هـا

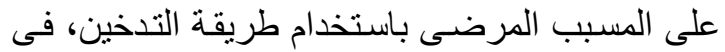


الثلاثنة عندما استخدمت طريقة أقر اص ورق الترشيح المشبعة بتلك الزيوت. وكان لزيت الزعتر أعلى تأثثر

تحكيم: أ.د ناجى بسن عبد الغفار

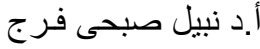

